\title{
EFFECT OF 4\% TITANIUM TETRAFLUORIDE SOLUTION ON THE EROSION OF PERMANENT AND DECIDUOUS HUMAN ENAMEL: AN IN SITU/EX VIVO STUDY
}

\author{
Ana Carolina MAGALHÃES ${ }^{1}$, Daniela RIOS ${ }^{2}$, Heitor Marques HONÓRIOª \\ Alberto Carlos Botazzo DELBEM ${ }^{4}$, Marília Afonso Rabelo BUZALAF ${ }^{5}$
}

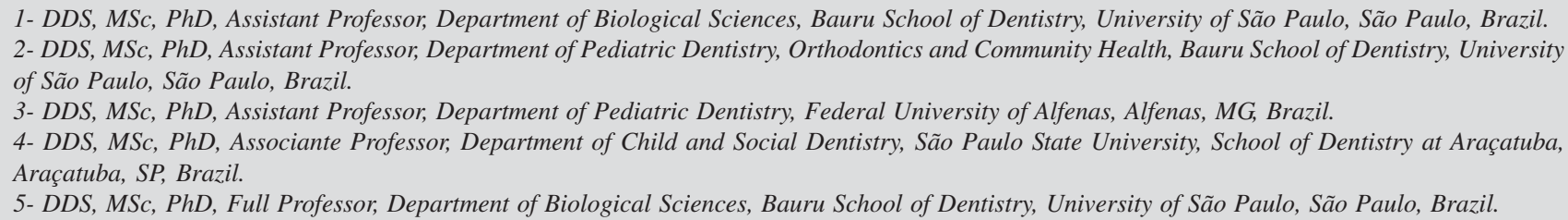

Corresponding address: Ana Carolina Magalhães - Departmento de Ciências Biológicas - FOB/USP - Bauru, SP - Al. Octávio Pinheiro Brisolla, 9-75, 17012-901 - Bauru, SP - Brasil - Phone +55-14-3235-8246 - Fax: +55-14-3234-3164 - e-mail: acm@usp.br

Received: March 24, 2008 - Modification: May 22, 2008 - Accepted: August 30, 2008

\begin{abstract}
7

in situ/ex vivo study assessed the effect of titanium tetrafluoride $\left(\mathrm{TiF}_{4}\right)$ solution on erosion of permanent $(\mathrm{P})$ and deciduous (d) human enamel. Ten volunteers wore acrylic palatal appliances containing 4 enamel samples, divided into two rows: TiF ${ }_{4}$ and no - $\mathrm{TiF}_{4}$ (control). Each row contained one deciduous and one permanent enamel sample. During the 1st day, formation of a salivary pellicle was allowed. At the $2^{\text {nd }}$ day, the $4 \% \mathrm{TiF}_{4}$ solution was applied on one row $\left(\mathrm{TiF}_{4}\right)$, while the other row remained untreated (control). From the $3^{\text {rd }}$ until the $7^{\text {th }}$ day, the samples were subjected to erosion by immersion in a cola drink for 5 min, 4 times/day. Enamel alterations were determined by microhardness testing (\%SMHC). Data were analyzed using 2 two-way ANOVA and Tukey's post hoc test $(\alpha=0.05)$. The mean $\% \mathrm{SMHC}( \pm \mathrm{SD})$ amounted to: $\mathrm{P}\left(\mathrm{TiF}_{4}-73.32 \pm 5.16\right.$ and control $\left.-83.49 \pm 4.59\right)$ and $\mathrm{d}\left(\mathrm{TiF} \mathrm{F}_{4}-83.01\right.$ \pm 7.41 and control $-75.75 \pm 2.57$ ). In conclusion, the application of $4 \% \mathrm{TiF}_{4}$ solution reduced the softening of permanent enamel but not of deciduous enamel significantly. However, no significant differences were detected between the permanent and deciduous enamel when the factor substrate was considered.
\end{abstract}

Key words: Dental erosion. Enamel. Fluoride. Titanium tetrafluoride.

\section{INTRODUCTION}

While there is a decline in the prevalence of dental caries in most developed countries ${ }^{19}$, an increasing prevalence of other dental disorders, such as dental erosion, has been observed $^{16}$. Dental erosion is defined as the loss of tooth substance by chemical processes (acids) not involving bacteria $^{16}$. The most important sources are dietary acids (acidic foods and drinks) ${ }^{14}$ and gastric acids (regurgitation and reflux disorders $)^{3}$. In modern societies, the increased consumption of acidic drinks, such as soft drinks, sport drinks, fruit juices and fruit teas, is becoming the most important factor in the etiology of dental erosion ${ }^{14,16}$.

Topical application of fluoride on dental hard tissues is considered as a major approach in the prevention of dental erosion. High-concentrated fluoride applications, such as oral rinses, gels or varnishes, have been considered as most effective in reducing the development of enamel erosion? ${ }^{7}$.
The fluoride agents that have been investigated in most in vitro studies about dental erosion are those that have been used over years for caries prevention: sodium fluoride (NaF), acidulated phosphate fluoride (APF), stannous fluoride $\left(\mathrm{SnF}_{2}\right)$ and amine fluoride $(\mathrm{AmF})$. More recently, the preventive effect of other fluoride agents, such as $4 \%$ titanium tetrafluoride $\left(\mathrm{TiF}_{4}\right)$ solution, have been investigated in erosion tests $\mathrm{s}^{5,9,10,17,21-26}$.

While some studies showed an inhibitory effect of $\mathrm{TiF}_{4}$ on erosion ${ }^{5,9,10,21,22-24}$, other studies did not found a protective effect ${ }^{17,25,26}$. In addition, studies evaluating the effect of this compound on deciduous enamel erosion are missing as yet. As some controversy remains about the susceptibility of deciduous teeth compared to permanent teeth to erosion ${ }^{1,11-}$ 13,15 , it is assumed that the efficacy of $\mathrm{TiF}_{4}$ on these substrates might also be different. Therefore, the purpose of this study was to assess the effect of $\mathrm{TiF}_{4}$ solution on permanent and deciduous human enamel subjected to erosion in situ/ex vivo. 


\section{MATERIAL AND METHODS}

\section{Enamel Samples and Palatal Appliance Preparation}

The experimental design of the study is illustrated in Figure 1.

Permanent $(4 \times 4 \times 3 \mathrm{~mm})$ and deciduous $(2 \times 2 \times 2 \mathrm{~mm})$ human enamel samples were prepared from freshly extracted impacted third molars and deciduous incisors, respectively. The teeth were sterilized by storage in $2 \%$ formaldehyde solution ( $\mathrm{pH}$ 7.0) for 30 days at room temperature ${ }^{27}$. The enamel surface of the samples was ground flat with watercooled 320-, 600- and 1200-grit $\mathrm{Al}_{2} \mathrm{O}_{3}$ papers (Buehler, Lake Bluff, IL, USA) and polished with felt paper wet by diamond spray $(1 \mu \mathrm{m}$; Buehler). The initial surface microhardness determination was performed by five indentations in the center of the enamel blocks (Knoop diamond, $25 \mathrm{~g}, 5 \mathrm{~s}$, HMV-2000; Shimadzu Corporation, Tokyo, Japan).

Twenty permanent and twenty deciduous enamel samples with a mean surface microhardness of $368.24 \pm 11.57 \mathrm{KHN}$ and $358.51 \pm 12.57 \mathrm{KHN}$, respectively, were randomly assigned to two groups ( $\mathrm{TiF}_{4}$ and control). Two cavities of $5 \times 5 \times 3 \mathrm{~mm}$ were prepared on the left and right sides of intraoral acrylic palatal appliances. Samples were allocated to treatments by stratified randomization according to the mean surface microhardness. In each row, one sample of permanent and deciduous enamel was fixed with wax.

\section{In Situ Phase}

This study was approved by the Research Ethics Committee of the Bauru School of Dentistry, University of São Paulo (Protocol \#78/2005). Ten healthy adult volunteers ( 6 females and 4 males, aged 19-30 years) residing in the same fluoridated area $(0.70 \mathrm{mgF} / \mathrm{L})$, who fulfilled the inclusion criteria described below, took part in this study. All participants presented normal salivary parameters ${ }^{6}$, such as adequate stimulated and non-stimulated salivary flows $(1.88 \pm 1.00 \mathrm{~mL} / \mathrm{min}$ and $0.60 \pm 0.33 \mathrm{~mL} / \mathrm{min}$, respectively) and salivary $\mathrm{pH}(7.32 \pm 0.30)$. No active erosive lesions or new carious cavities were found.

The volunteers wore acrylic palatal appliances containing 4 human enamel samples, divided into two rows: $\mathrm{TiF}_{4}$ and no- $\mathrm{TiF}_{4}$ (control). Each row contained one deciduous and one permanent enamel sample. In the first $24 \mathrm{~h}$, the samples were not subjected to erosive process in order to allow the formation of a salivary pellicle ${ }^{8}$. At the $2^{\text {nd }}$ day, the application of the fluoride solution $\left(4 \% \mathrm{TiF}_{4}\right)$ was made extraorally by one of the researchers. The 4\% (1.29 M F) $\mathrm{TiF}_{4}$ solution was prepared by dissolution of powdered $\mathrm{TiF}_{4}$ (Aldrich Chemical Company, Milwaukee, WI, USA) in deionized water. The $\mathrm{pH}$ of the fresh solution amounted to 1.2. The $\mathrm{TiF}_{4}$ solution was applied in drops for $1 \mathrm{~min}$ on one row $\left(\mathrm{TiF}_{4}\right)$, while the other row remained untreated (control). The drop was left undisturbed until the surface appeared dry. Additional drops were applied in the same

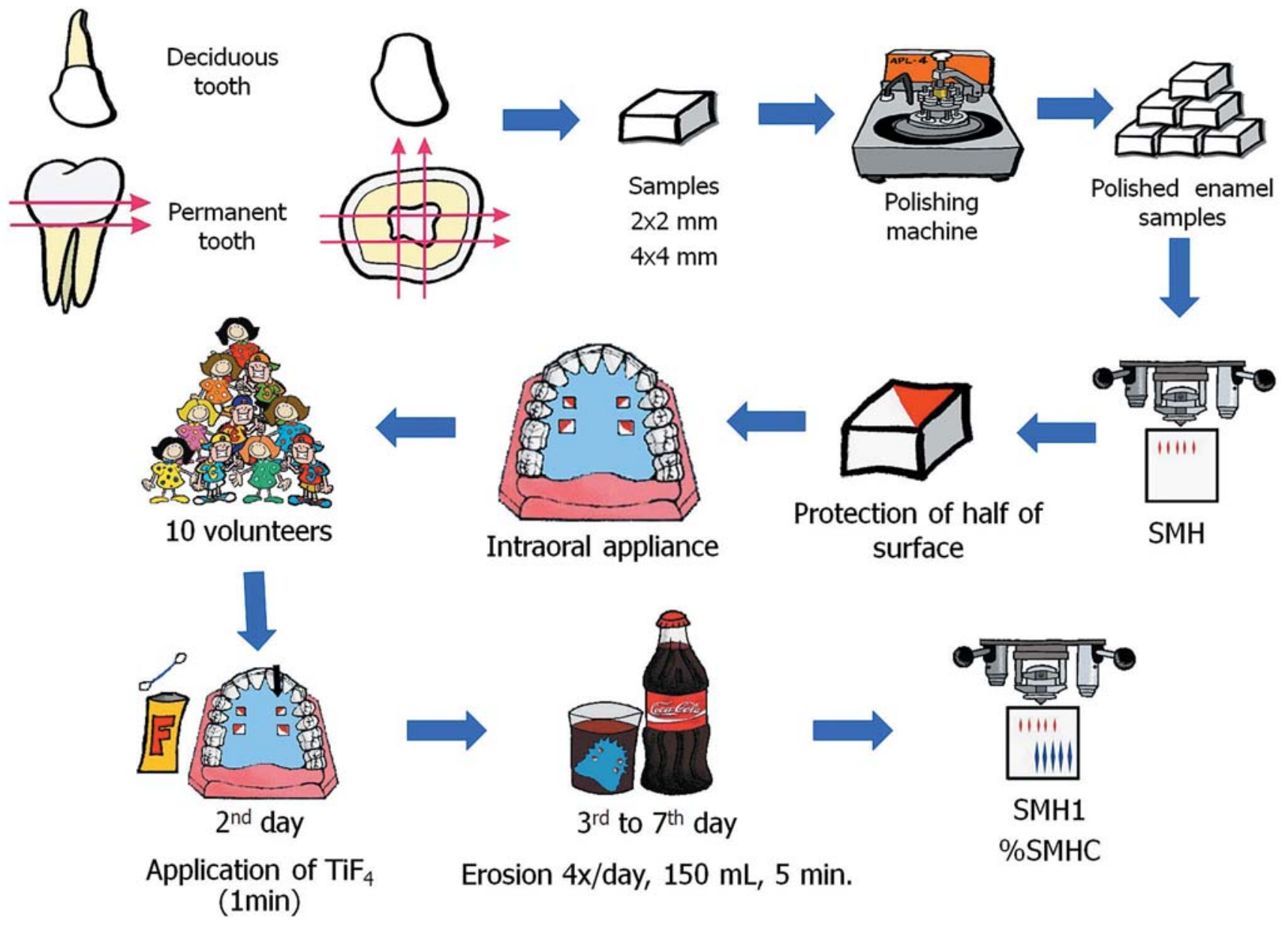

FIGURE 1- Experimental design of the study 
TABLE 1- Mean and standard deviation of $\mathrm{SMH}, \mathrm{SMH1}$ and $\% \mathrm{SMHC}_{\mathrm{B}}$ of $\mathrm{TiF}_{4}$-treated and untreated permanent and deciduous enamel

\begin{tabular}{|c|c|c|c|c|c|c|c|}
\hline \multirow[t]{2}{*}{ Factors } & \multicolumn{3}{|c|}{ Permanent } & \multicolumn{3}{|c|}{ Deciduous } & \multirow[b]{2}{*}{ Mean "Treatment" } \\
\hline & SMH & SMH1 & $\%$ SMHC & SMH & SMH1 & \%SMHC & \\
\hline $\mathrm{TiF}_{4}$ & $\begin{array}{l}366.28 \pm \\
7.41^{a}\end{array}$ & $\begin{array}{l}97.72 \pm \\
23.79\end{array}$ & $\begin{array}{l}73.32 \pm \\
11.65\end{array}$ & $\begin{array}{l}358.52 \pm \\
5.16^{b}\end{array}$ & $\begin{array}{l}60.9 \pm \\
19.77\end{array}$ & $\begin{array}{l}83.01 \pm \\
11.78\end{array}$ & $\begin{array}{c}78.17 \pm 7.87 \\
\text { (n.s.) }\end{array}$ \\
\hline Control & $\begin{array}{l}370.2 \pm \\
2.56^{\mathrm{b}}\end{array}$ & $\begin{array}{l}57.68 \pm \\
10.23\end{array}$ & $\begin{array}{l}84.42 \pm \\
14.05\end{array}$ & $\begin{array}{l}358.08 \pm \\
5.19^{a}\end{array}$ & $\begin{array}{l}86.82 \pm \\
18.93\end{array}$ & $\begin{array}{l}75.75 \pm \\
11.65\end{array}$ & $\begin{array}{c}80.09 \pm 5.98 \\
\text { (n.s.) }\end{array}$ \\
\hline \multicolumn{8}{|l|}{ Mean } \\
\hline "Substrate" & $\begin{array}{l}368.24 \pm \\
12.56^{*}\end{array}$ & & $\begin{array}{l}78.87 \pm \\
7.61 \\
\text { (n.s) }\end{array}$ & $\begin{array}{l}358.30 \pm \\
11.58^{\star}\end{array}$ & & $\begin{array}{l}79.38 \pm \\
6.56 \\
\text { (n.s) }\end{array}$ & \\
\hline
\end{tabular}

Values followed by "n.s." means no significant differences for the both factors (two-way ANOVA, p>0.05). Values followed by different superscripts letters indicate statistically significant differences between the groups (Tukey's test, $n=10, p<0.05$ ). * indicates a significant difference between the initial surface microhardness of permanent enamel and deciduous enamel (Student t' test, $n=20, p<0.01$ ).

manner until 1 min had elapsed ${ }^{23}$. After that, the excess of the solution was removed with a cotton swab.

From the $3^{\text {rd }}$ to the $7^{\text {th }}$ day, erosive challenges were made extraorally 4 times a day and at predetermined times (8:00am, 12:00pm, 4:00pm and 8:00 pm). For erosion of the samples, the volunteers were instructed to remove the palatal appliance and immerse it in a cup containing 150 $\mathrm{mL}$ of a freshly opened bottle of regular Coke ${ }^{\circledR}(\mathrm{pH}-2.6$, $32.1 \mathrm{mg} \mathrm{Ca} / \mathrm{L}, 18.1 \mathrm{mg}$ P/L, $0.26 \mathrm{ppm}$ of F, $0.1 \mathrm{~mL}$ of $0.2 \mathrm{M}$ $\mathrm{NaOH}$ to increase one unit $\mathrm{pH}$ in $3 \mathrm{~mL}$ of drink; Spal, Porto Real, RJ, Brazil). Immersion of the enamel samples was performed for $5 \mathrm{~min}$ at room temperature.

The volunteers received instructions to wear the appliances continuously, even at night, and remove them at meals ( 3 times a day, $1 \mathrm{~h}$ /each meal). During this period the appliance was stored in wet gauze. Oral hygiene was performed right after meals using a fluoridated dentifrice $\left(1,500\right.$ ppm F, Sorriso ${ }^{\circledR}$, Brazil). Subsequently, the appliance was replaced into the mouth.

\section{Microhardness Measurement}

Five indentations were made in the center of the permanent and deciduous enamel samples each $100 \mu \mathrm{m}$ apart from the other (Knoop diamond, 25 g, 5 s, HMV-2000; Shimadzu Corporation, Tokyo, Japan). Microhardness was assessed prior to the treatments (baseline: $\mathrm{SMH}$ ) and after the in situ phase (final: SMH1). The percentage of surface microhardness change was calculated as follows: $\% \mathrm{SMHC}=$ $[100 *(\mathrm{SMH} 1-\mathrm{SMH} / \mathrm{SMH})]$.

\section{Statistical Analysis}

The software GraphPad for Windows (San Diego, CA, USA) was used. The assumptions of equality of variances and normal distribution of errors were checked for all tested variables. Since the assumptions were satisfied, two-way repeated-measures ANOVA (factors dental substrate and fluoride) and Tukey's post hoc tests were carried out for statistical comparisons. For comparison between the initial surface microhardness of permanent and deciduous enamel, Student's t test was performed. The significance limit was set at $5 \%$.

\section{RESULTS}

Table 1 shows the mean $\mathrm{SMH}$ and $\mathrm{SMH} 1$ as well as the $\%$ SMHC $( \pm$ SD) of permanent and deciduous enamel. The initial surface microhardness of deciduous enamel was significantly lower than the permanent enamel (student's t test, $\mathrm{p}=0.01$ ). With regard to the $\% \mathrm{SMHC}$ (softening), no significant differences were found for the factors "type of dental substrate" $(\mathrm{F}=0.367, \mathrm{p}=0.54)$ and "fluoride treatment" $(\mathrm{F}=0.719, \mathrm{p}=0.40)$. However, a significant interaction between the two factors was found (two-way ANOVA, $\mathrm{F}=27.157, \mathrm{p}<0.0001)$. Analysis by Tukey's test showed that the application of the $4 \% \mathrm{TiF}_{4}$ solution reduced the softening of permanent enamel significantly $(\mathrm{p}<0.05)$. In contrast, softening of deciduous enamel was significantly higher when the $\mathrm{TiF}_{4}$ solution was applied $(\mathrm{p}<0.05)$.

\section{DISCUSSION}

In order to simulate the daily life situation as closely as possible, an in situl ex vivo model was chosen to test the effect of $\mathrm{a} \mathrm{TiF}_{4}$ solution on erosion of permanent and deciduous human enamel. To the best of our knowledge, this is the first study evaluating the effect of $\mathrm{TiF}_{4}$ on erosion of deciduous teeth in situ/ ex vivo. Professionally applied highly fluoridated solutions, gels or varnishes are recommended for individuals who present moderate to severe dental erosion, with the objective to prevent new or 
recurrent dental erosion ${ }^{28}$

To simulate the professional application of the $\mathrm{TiF}_{4}$ agent by a dentist, the solution was applied only once. The excess of the solution was removed before the appliance was replaced into the mouth to avoid any carry-across effect of the treatment. Measurement of the surface microhardness immediately after application of the $\mathrm{TiF}_{4}$ solution was not performed to allow for remineralization of the enamel surface and stabilization of the titanium glaze layer. However, as the $\mathrm{TiF}_{4}$ solution presents an acidic $\mathrm{pH}$, further studies should evaluate the surface hardness change immediately after its application. Similar to previous studies, surface microhardness (\%SMHC) was used as response variable since it is a suitable tool for determination of early stages of enamel dissolution ${ }^{2}$.

Regarding to the dental substrates, deciduous enamel and dentin are thinner than permanent. Therefore, the erosive process reaches the dentin earlier and leads to an advanced lesion after a shorter exposure period to acids, when compared to permanent teeth ${ }^{11}$. However, the analysis of the susceptibility to erosive softening of permanent and deciduous dental hard tissues revealed conflicting results ${ }^{1,11}$ ${ }^{13,15}$. Deciduous enamel is assumed to be more susceptible than permanent enamel when the initial softening passes into a progressive mineral dissolution and surface loss. The different susceptibility to erosion of permanent and deciduous enamel might increase rather over time and/or with increasing erosive capacity of the $\mathrm{acid}^{11}$. In the present study, deciduous enamel presented significant lower initial surface microhardness than permanent enamel. However, neither of the substrates differed significantly in the degree of acid softening, when only the factor "substrate" was considered in the statistical analysis.

The results of present study showed that the $\mathrm{TiF}_{4}$ solution was able to reduce the softening of permanent enamel. The protective action of $\mathrm{TiF}_{4}$ has been attributed not only to the action of fluoride, but also to the action of titanium ${ }^{4,22}$. The low $\mathrm{pH}$ of the $\mathrm{TiF}_{4}$ solution (around 1.2), favors the linking between titanium and oxygen of the group phosphate, leading to the formation of a titanium dioxide glaze-like layer on the surface ${ }^{5,23}$. This glaze-like layer might be associated with a decreased softening of the enamel surface. It is speculated that the titanium ions might play an important role as they might substitute calcium in the apatite lattice ${ }^{18,20}$. Moreover, it is suggested that titanium interacts with the enamel surface because of the low $\mathrm{pH}$ of the agent, thus leading to an increased fluoride uptake by enamel ${ }^{18}$.

In contrast to permanent enamel, the $\mathrm{TiF}_{4}$ solution increased the \% SMHC in deciduous enamel. One hypothesis to explain this unexpected result is that the low $\mathrm{pH}$ of the $\mathrm{TiF}_{4}$ solution (1.2) could cause greater enamel loss on application ${ }^{26}$ because the deciduous enamel is less mineralized and thinner than the permanent enamel. Thus, deciduous enamel might be more susceptible to alterations caused by the $\mathrm{TiF}_{4}$ solution, which has a lower $\mathrm{pH}$ when compared to the most commonly consumed erosive drinks (pH 2.6). This result confirms previous findings that the erosion susceptibility of deciduous enamel increased with a higher erosivity of the acid ${ }^{11}$.

\section{CONCLUSION}

The $\mathrm{TiF}_{4}$ solution was able to reduce permanent enamel softening caused by the erosive challenge in situ. In contrast, softening of deciduous enamel was increased by the treatment compared to control. Since both substrates exhibited a relatively high surface softening after the erosive challenge, the protective capacity of $\mathrm{TiF}_{4}$ has to be evaluated in further studies.

\section{ACKNOWLEDGEMENTS}

The authors would like to thank FAPESP - The São Paulo State Research Foundation (Grant \#05/54203-3 to the first author) for the financial support.

\section{REFERENCES}

1- Amaechi BT, Higham SM, Edgar WM. Factors influencing the development of dental enamel in vitro: enamel type, temperature and exposure time. J Oral Rehabil. 1999;26:624-30.

2- Attin T. Methods for assessment of dental erosion. Monogr Oral Sci. 2006;20:152-72.

3- Bartlett D. Intrinsic causes of erosion. Monogr Oral Sci. 2006;20:11939.

4- Buyukyilmaz T, Ögaard B, Duschner H, Ruben J, Arends J. The cariespreventive effect of titanium tetrafluoride on root surfaces in situ as evaluated by microradiography and confocal laser scanning microscopy. Adv Dent Res. 1997;11:448-52.

5- Buyukyilmaz T, Ogaard B, Rolla G. The resistance of titanium tetrafluoride-treated human enamel to strong hydrochloric acid. Eur J Oral Sci. 1997;105:473-7.

6- Dawes C. Physiological factors affecting salivary flow rate, oral sugar clearance, and the sensation of dry mouth in man. J Dent Res. 1987;66:64853.

7- Ganss C, Klimek J, Brune V, Schurmann A. Effects of two fluoridation measures on erosion progression in human enamel and dentine in situ. Caries Res. 2004;38:561-6.

8- Hara AT, Ando M, Gonzalez-Cabezas C, Cury JA, Serra MC, Zero DT. Protective effect of the dental pellicle against erosive challenges in situ. J Dent Res. 2006;85:612-6.

9- Hove L, Holme B, Øgaard B, Willumsen T, Tveit AB. The protective effect of $\mathrm{TiF}_{4}, \mathrm{SnF}_{2}$ and $\mathrm{NaF}$ on erosion of enamel by hydrochloric acid in vitro measured by white light interferometry. Caries Res. 2006;40:440-3.

10- Hove LH, Young A, Tveit AB. An in vitro study on the effect of $\mathrm{TiF}_{4}$ treatment against erosion by hydrochloric acid on pellicle-covered enamel. Caries Res. 2007;41:80-4.

11- Hunter ML, West NX, Hughes JA, Newcombe RG, Addy M. Erosion of deciduous and permanent dental hard tissue in the oral enviromment. $\mathrm{J}$ Dent. 2000;28:257-63.

12- Johansson AK, Sorvari R, Birkhed D, Meurman JH. Dental erosion in deciduous teeth - an in vivo and in vitro study. J Dent. 2001;29:33340 . 
13- Lippert F, Parker DM, Jandt KD. Susceptibility of deciduous and permanent enamel to dietary acid-induced erosion studied with atomic force microscopy nanoindentation. Eur J Oral Sci. 2004;112:61-6.

14- Lussi A, Jaeggi T, Zero D. The role of diet in the aetiology of dental erosion. Caries Res. 2004;38:34-44.

15- Lussi A, Kohler N, Zero D, Schaffner M, Megert B. A comparison of the erosive potential of different beverages in primary and permanent teeth using an in vitro model. Eur J Oral Sci. 2000;108:110-4.

16- Lussi A. Erosive tooth wear - a multifactorial condition of growing concern and increasing knowledge. Monogr Oral Sci. 2006;20:1-8.

17- Magalhães AC, Rios D, Honório HM, Jorge AM Jr, Delbem ACB, Buzalaf MAR. Effect of $4 \%$ titanium tetrafluoride solution on denta erosion by a soft drink: an in situ/ex vivo study. Arch Oral Biol. 2008;53:399-404.

18- Mundorff SA, Little MF, Bibby BG. Enamel dissolution. 2. Action of titanium tetrafluoride. J Dent Res. 1972;51:1567-71.

19- Peterson G, Bratthall D. The caries decline: a review of reviews. Eur J Oral Sci. 1996;104:436-43.

20- Ribeiro CC, Gibson I, Barbosa MA. The uptake of titanium ions by hydroxiapatite particles - structural changes and possible mechanisms. Biomaterials. 2006;27:1749-61

21- Schlueter N, Ganss C, Mueller U, Klimek J. Effect of titanium tetrafluoride and sodium fluoride on erosion progression in enamel and dentine in vitro. Caries Res. 2007;41:141-5.

22- Tezel H, Ergucu Z, Onal B. Effects of topical fluoride agents on artificial enamel lesion formation in vitro. Quintessence Int. 2002;33:34752 .

23- Tveit AB, Hals E, Isrenn $\mathrm{R}$, Totdal $\mathrm{B}$. Highly acid $\mathrm{SnF}_{2}$ and $\mathrm{TiF}_{4}$ solution. Caries Res. 1983;17:412-8.

24- van Rijkom H, Ruben J, Vieira A, Huysmans MC, Truin GJ, Mulder J. Erosion-inhibiting effect of sodium fluoride and titanium tetrafluoride treatment in vitro. Eur J Oral Sci. 2003;111:253-7.

25- Vieira A, Lugtenborg M, Ruben JL, Huysmans MC. Brushing abrasion of eroded bovine enamel pretreated with topical fluorides. Caries Res. 2006; 40:224-30.

26- Vieira A, Ruben JL, Huysmans MC. Effect of titanium tetrafluoride, amine fluoride and fluoride varnish on enamel erosion in vitro. Caries Res. 2005;39:371-9.

27- White DJ. Reactivity of fluoride dentifrices with artificial caries 1 . Effects on early lesions: F uptake, surface hardening and remineralisation. Caries Res. 1987;21:126-40.

28- Wiegand A, Attin T. Influence of fluoride on the prevention of erosive lesions - a review. Oral Health Prev Dent. 2003;1:245-53. 